\title{
EFFECTS OF DIFFERENT NITROGEN APPLICATION STRATEGIES ON THE WATER AND NITROGEN USE EFFICIENCY OF GREENHOUSE TOMATOES (SOLANUM LYCOPERSICUM L.)
}

\author{
NIE, K. K. ${ }^{1}-$ ZHANG, M. Z. ${ }^{1,2,3}-$ BAI, Q. J. ${ }^{1 *}-$ LI, Y. ${ }^{3}$ \\ ${ }^{1}$ State Key Laboratory of Eco-hydraulics in Northwest Arid Region of China, Xi'an University \\ of Technology, Xi'an 710048, Shaanxi, China \\ ${ }^{2}$ Henan Provincial Water Conservancy Research Institute, Zhengzhou 450000, China \\ ${ }^{3}$ Northwest Land and Resources Research Center, Shaanxi Normal University, Xi'an 710119, \\ Shaanxi, China \\ *Corresponding author \\ e-mail: qjb0206@163.com
}

(Received 23 $3^{\text {rd }}$ Mar 2021; accepted $19^{\text {th }}$ Jul 2021)

\begin{abstract}
Improvements in nitrogen use efficiency (NUE) reduce stress on the environment and improve vegetable production. The effects of the application rate and injection timing of nitrogen $(\mathrm{N})$ on the net photosynthetic rate $\left(P_{n}\right)$, soil enzyme activities, yield $(Y)$, water use efficiency (WUE), and nitrogen use efficiency $(N U E)$ of tomato were studied by conducting an experiment with a split block design in which $\mathrm{N}$ was applied at different rates $\left(150 \mathrm{~kg} \cdot \mathrm{ha}^{-1}, \mathrm{~N} 1 ; 200 \mathrm{~kg} \cdot \mathrm{ha}^{-1}, \mathrm{~N} 2\right.$; and $\left.250 \mathrm{~kg} \cdot \mathrm{ha}^{-1}, \mathrm{~N} 3\right)$ and timings (first $1 / 3$ of irrigation, $\mathrm{S} 1$; middle $1 / 3$ of irrigation, $\mathrm{S} 2$; and last $1 / 3$ of irrigation, $\mathrm{S} 3$ ); no $\mathrm{N}$ fertilizer was applied in the control. The results showed an appropriate $\mathrm{N}$ application rate (i.e., not too high or low) can improve $P_{n}$ and soil enzyme activity. The $Y$ and $W U E$ of greenhouse tomato increased non-linearly with the increase in $\mathrm{N}$ application rate, but $N U E$ first increased and then decreased as the $\mathrm{N}$ application rate increased. Compare to $\mathrm{S} 1, \mathrm{~S} 2$ and $\mathrm{S} 3$ improved the $P_{n}$, soil enzyme activities, $Y, W U E$, and NUE of tomato. These results could be used to promote $\mathrm{N}$ conservation and high $\mathrm{Y}$ of facility agriculture crops.
\end{abstract}

Keywords: facility agriculture, nitrogen application rate, nitrogen injection timing, soil enzyme activity, yield

\section{Introduction}

Facility agriculture is a form of modern agriculture in which engineering technology is leveraged to efficiently produce animals and plants under controllable environmental conditions. Greenhouse technology is commonly used in facility agriculture and plays an important role in meeting the increasing demand for vegetables. For instance, the area of protected vegetable cultivation in China has increased from 10,300 ha in 1982 to 4.05 million ha in 2019 , accounting for $30.5 \%$ of the total area of vegetable cultivation, and the area of solar greenhouses and large and medium sheds in particular exceeds 2.7 million ha.

Tomato (Solanum lycopersicum L.) is one of the main vegetables of facility agriculture and is highly nutritious (Liu et al., 2019; Toor et al., 2006). As of 2019, the cultivated area of tomatoes in the world is 5.03 million ha, accounting for $8.43 \%$ of the total area of vegetables cultivation. According to the statistics, the total world production of tomatoes in 2019 was 180.77 million tons (FAOSTAT, 2019). Tomato production requires a large amount of nitrogen $(\mathrm{N})$, especially in the greenhouse production process; however, excessive $\mathrm{N}$ input (Rashti et al., 2015; Ju et al., 2006; Min et al., 2012) can increase the risk of $\mathrm{N}$ loss (Zhu et al., 2002) and lead to several 
environmental problems. One of the main current challenges in vegetable production is finding ways to improve nitrogen use efficiency $(N U E)$ and reduce the $\mathrm{N}$ application rate without compromising crop yield $(Y)$ (Huang et al., 2012; Shi et al., 2020; Barth et al., 2019). Research on greenhouse water and fertilizer technology could make important contributions to the sustainable development of agriculture.

Many studies have examined the effect of $\mathrm{N}$ application rate on greenhouse tomatoes. For example, Mahajan et al. (2006) showed that 50\% evapotranspiration (ET) irrigation rate and $137 \mathrm{~kg} \cdot \mathrm{ha}^{-1} \mathrm{~N}$ application rate could significantly increase tomato $Y$ in a greenhouse. Du et al. (2017) showed that the optimal $\mathrm{N}$ application rate for maximizing $Y$ and water use efficiency (WUE) was $250 \mathrm{~kg} \cdot \mathrm{ha}^{-1}$, whereas $150 \mathrm{~kg} \mathrm{~N} \cdot \mathrm{ha}^{-1}$ was optimal for maximizing NUE. Li et al. (2020) studied the WUE, NUE, and quality of greenhouse tomatoes under different water and $\mathrm{N}$ management strategies and found that the optimal water and $\mathrm{N}$ management strategy was $70 \%$ ET irrigation rate and $150 \mathrm{~kg} \cdot \mathrm{ha}^{-1} \mathrm{~N}$ application rate. These results indicate that the optimal $\mathrm{N}$ application rate for greenhouse tomatoes depends on the experimental objectives and environmental factors.

The method of $\mathrm{N}$ application can also affect the $N U E$ by altering the distribution of $\mathrm{N}$ in soil. Khakural et al. (2005) characterized variation in the urea hydrolysis rate at different application depths $(0 \sim 60 \mathrm{~cm})$ and found that the hydrolysis rate decreased as the $\mathrm{N}$ application depth increased. This result indicates that the $\mathrm{N}$ supply capacity of different soil layers varies. The uneven distribution of crop roots in soil layers (Outoukarte et al., 2010; Qiu et al., 2017) can also lead to differences in the NUE of crops in different soil layers (Matimati et al., 2014). Kaushal et al. (2005) found that applying slow-release $\mathrm{N}$ fertilizer at a depth of $20 \mathrm{~cm}$ could increase soybean $Y$ by increasing the number of pods and grains. As drip irrigation events are usually long (more than $2 \mathrm{~h}$ ), variation in nutrient injection timing via drip irrigation can affect the $\mathrm{N}$ distribution in the soil (Hanson et al., 2006). Thus, a major goal of current research is determining the optimal nutrient injection timing under drip irrigation. Li et al. (2004) conducted laboratory experiments and showed that irrigation in the first quarter, fertilization in the next two quarters, and irrigation in the last quarter of the experimental period were effective for keeping most of the nitrate-nitrogen $\left(\mathrm{NO}_{3}{ }^{-}-\mathrm{N}\right)$ in the root zone of crops. Gärdenäs et al. (2005) simulated the effects of fertilization strategy and soil type on nitrate leaching in four micro-irrigation systems and found that fertilization later in the irrigation process can reduce nitrate leaching. Therefore, the timing of water and fertilizer application can affect the nutrient distribution in the soil and thus the growth and $Y$ of crops. However, the effect of the timing of both water and fertilizer application has not been studied in greenhouse tomatoes to date.

Here, the effect of different $\mathrm{N}$ application strategies on the $\mathrm{N}$ distribution in greenhouse soil and the growth of greenhouse tomatoes was studied through a greenhouse experiment and multi-objective optimization analysis. The results of this study provide new insights that could be used to improve the integration of irrigation and fertilizer technology. These results also have implications for improving $\mathrm{N}$ conservation and the $Y$ of facility agriculture crops.

\section{Materials and methods}

\section{Experimental site}

The experiment was conducted from March 23, 2019 to January 30, 2020 in a greenhouse of the Modern Agricultural Science and Technology Exhibition Center of 
Xi'an City, Shaanxi Province, China $\left(34^{\circ} 03^{\circ} \mathrm{N}, 108^{\circ} 52^{\circ} \mathrm{E} ; 435 \mathrm{~m}\right)$. The region is characterized by a warm temperate semi-humid continental monsoon climate. The annual average temperature is $13.3{ }^{\circ} \mathrm{C}$, the annual average rainfall is $507.7 \sim 719.8 \mathrm{~mm}$, the precipitation from August to October accounts for more than $60 \%$ of the annual precipitation, the frost-free period is 219 233 days, the maximum annual sunshine time is $2230 \mathrm{~h}$, and the multi-year average wind speed is $2 \sim 3$. The average bulk density of the $1.0 \mathrm{~m}$ soil layer is $1.53 \mathrm{~g} \cdot \mathrm{cm}^{-3}$, the water holding capacity of the soil is $25.40 \%$, and the depth of the groundwater table is greater than $30 \mathrm{~m}$. The soil is sandy loam. The organic matter, total phosphorus $(\mathrm{P})$, total potassium $(\mathrm{K})$, total $\mathrm{N}$, available $\mathrm{N}$, available $\mathrm{P}$, and available $\mathrm{K}$ content in the plough layer before sowing were $10.62 \mathrm{~g} \cdot \mathrm{kg}^{-1}, 7.24 \mathrm{~g} \cdot \mathrm{kg}^{-1}$, $3.29 \mathrm{~g} \cdot \mathrm{kg}^{-1}, 0.94 \mathrm{~g} \cdot \mathrm{kg}^{-1}, 68.41 \mathrm{mg} \cdot \mathrm{kg}^{-1}, 97.74 \mathrm{mg} \cdot \mathrm{kg}^{-1}$, and $74.25 \mathrm{mg} \cdot \mathrm{kg}^{-1}$, respectively.

\section{Field management}

The greenhouse $(85 \mathrm{~m}$ long $\times 15 \mathrm{~m}$ wide) was oriented from north to south. The tomato variety "Jingfan 401" (Jingyan Yinong Seed Sci-tech Co. Ltd., Beijing, China) (Fig. 1) is a hybrid of pink tomato, early maturity, indeterminate growth type, round fruit, single fruit weight 200 260 g, good hardness. The tomato was planted on a ridge with a row spacing of $50 \mathrm{~cm}$ and a plant spacing of $40 \mathrm{~cm}$. The length of the ridge was $3.4 \mathrm{~m}$. A $1.0 \mathrm{~m}$ deep building waterproof film made of styrene-butadiene-styrene block copolymer was buried in the middle to prevent the horizontal infiltration and movement of soil moisture. Plastic barriers were also placed in the middle to prevent diseases and insect pests associated with the excessive humidity of the irrigation treatments from affecting other plots (Fig. 2). During seeding stage, the vents were opened when the interior temperature was higher than $30^{\circ} \mathrm{C}$. After the middle of April, if the lowest interior temperature stabilized above $15^{\circ} \mathrm{C}$, the vents were opened except on rainy days, until the end of the spring tomatoes experiment. After the middle of October, if the lowest interior temperature was below $10^{\circ} \mathrm{C}$, the warm-air machines were turned on. After management, the maximum daily temperature of spring tomato in the greenhouse generally occurs at 12 14:00 p.m. (the average is $33.6^{\circ} \mathrm{C}$ ), the lowest temperature generally occurs at 6 7:00 a.m. (the average is $18.4{ }^{\circ} \mathrm{C}$ ), and the maximum humidity (relative humidity) generally occurs at 6 8:00 a.m. or 19 23:00 p.m. (the average is 84.6\%), the lowest humidity generally occurs at $12 \sim 14: 00$ p.m. (the average is $36 \%$ ). The highest daily temperature of autumn tomato in the greenhouse generally occurs at 12 14:00 p.m. (the average is $24.1{ }^{\circ} \mathrm{C}$ ). The lowest temperature generally occurs at 7 9:00 a.m. (the average is $13.9{ }^{\circ} \mathrm{C}$ ). The highest humidity generally occurs at 7 9:00 a.m. or 20 24:00 p.m. (the average is $89.4 \%$ ), and the lowest humidity generally occurs at 12 14:00 p.m. (the average is $44.1 \%$ ). Other agronomic practices, such as weeding, pest control, and pollination were same for all treatments, following the local agronomic practices.

The source of the irrigation water was groundwater. To ensure the survival of seedlings on the day of planting, the irrigation amount of first time $\left(I_{l}, 32.9 \mathrm{~mm}\right.$ for spring and $31.2 \mathrm{~mm}$ for autumn) was based on local tomato planting experience. Spring tomatoes were planted on March 27, 2019, and the irrigation treatment began on April 4, 2019 and ended on July 11, 2019. Autumn tomatoes were planted on August 27, 2019, and the irrigation treatment began on September, 4, 2019 and ended on January, 11, 2020. The growth stage of tomato was divided into three stages based on the characteristic features of tomato growth and development: flowering stage (0 30 d after transplanting (W1)), expansion stage (30 90 d after transplanting (W2)), and maturity stage (90 d after transplanting W3). 


$$
\text { - } 3242 \text { - }
$$
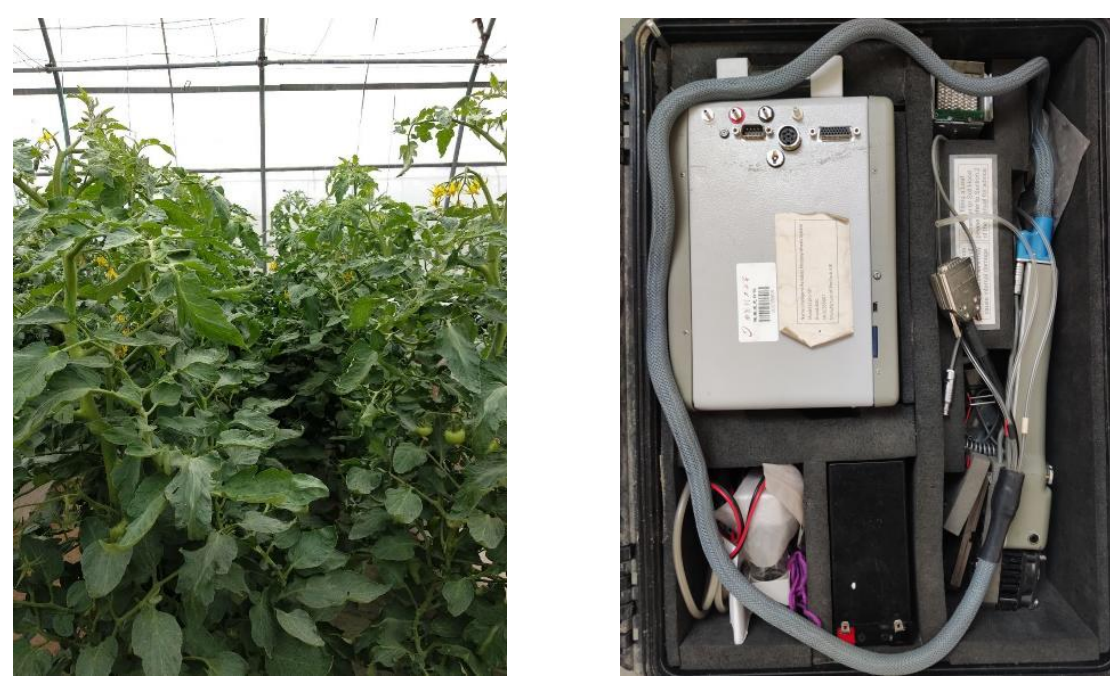

Figure 1. Field figure of tomato experiment in greenhouse (left) and LCpro-SD portable photosynthesis system (right)

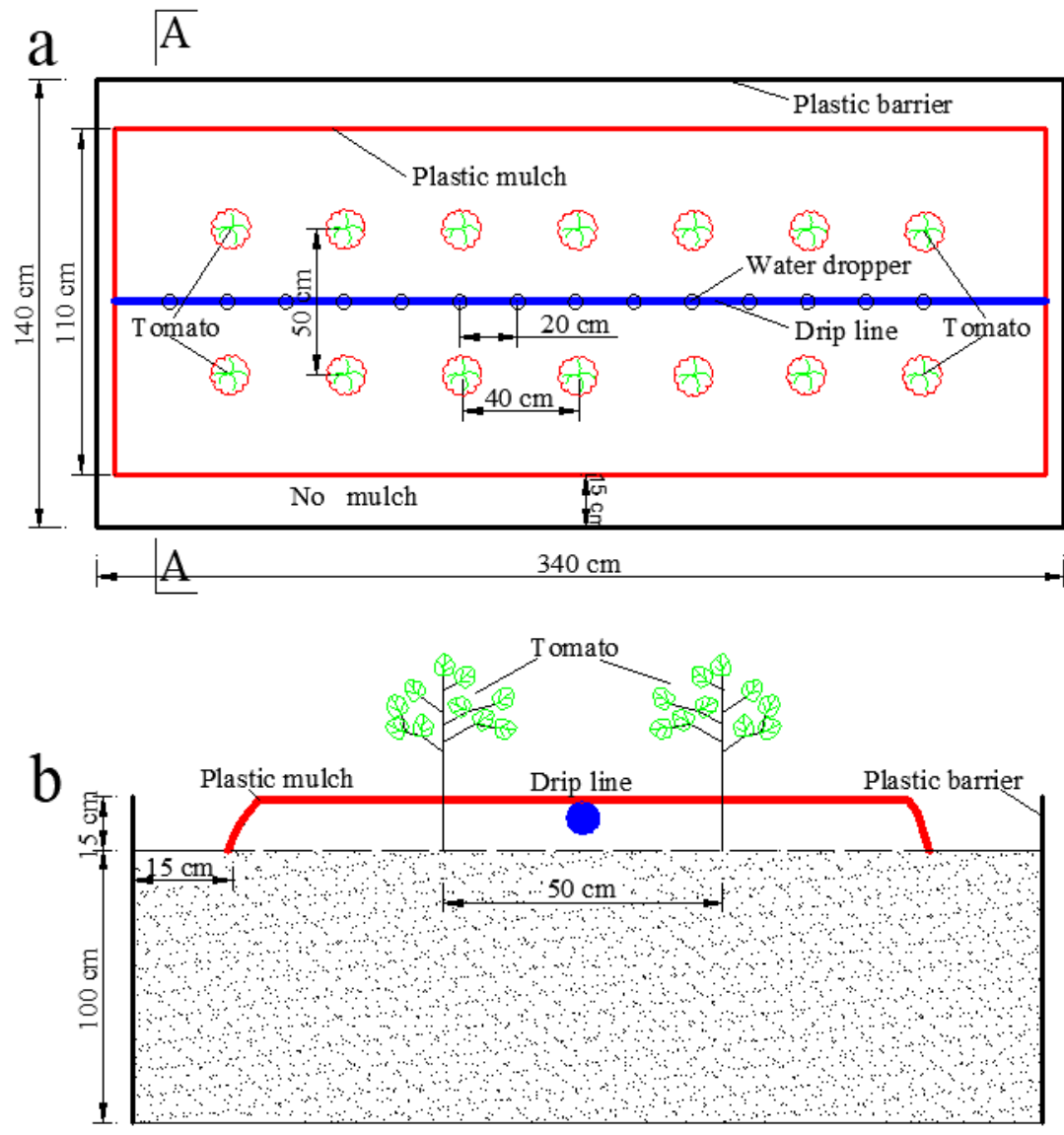

Figure 2. (a) the planform of tomato planting pattern, and drip-line arrangements in a planting plot; (b) section map of " $A-A$ "

The subsequent irrigation amount $\left(I_{2}\right)$ was controlled based on the cumulative evaporation from a $20 \mathrm{~cm}$ diameter pan $\left(E_{p a n}\right)$ (Agbna et al., 2017). The evaporation 
amount was measured at 08:00 am every $5 \mathrm{~d}$. Irrigation was carried out after measurements. Figure 3 shows the $I_{2}$ over the experimental period; $I_{2}$ was calculated according to Equation 1 (Liu et al., 2013):

$$
I_{2}=E_{p a n} \times k_{c p}
$$

where $E_{p a n}$ is the evaporation between two irrigation events in mm and $k_{c p}$ is the croppan coefficient. In this paper, the crop-pan coefficient of $k_{c p}$ was 1.0 (Zhao et al., 2009; Zhang et al., 2020).

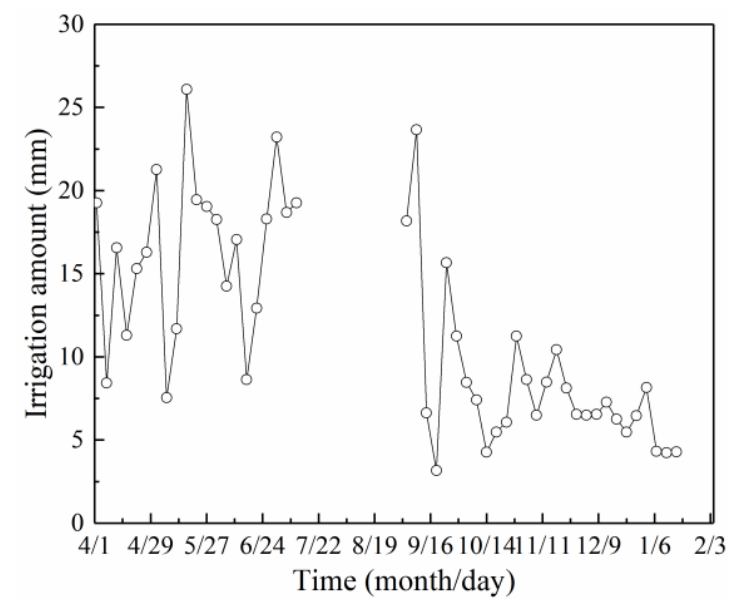

Figure 3. Irrigation records over the experimental period (4/4/2019-7/11/2019 and 9/4/2019$1 / 11 / 2020)$

\section{Experimental design}

Nitrogen application rate $(\mathrm{N})$ and injection timing $(\mathrm{S})$ were the two factors in the experiment; the details of the experimental design are shown in Table 1.

Table 1. Test factors and experimental design

\begin{tabular}{c|c|c}
\hline Test number & Injection timing of $\mathbf{N}$ during irrigation & Nitrogen application rate $\mathbf{( k g} \cdot \mathbf{h a}^{\mathbf{- 1}} \mathbf{)}$ \\
\hline N1S1 & First $1 / 3$ & 150 \\
N1S2 & Middle 1/3 & 150 \\
N1S3 & Last $1 / 3$ & 150 \\
N2S1 & First $1 / 3$ & 200 \\
N2S2 & Middle $1 / 3$ & 200 \\
N2S3 & Last $1 / 3$ & 200 \\
N3S1 & First 1/3 & 250 \\
N3S2 & Middle 1/3 & 250 \\
N3S3 & Last 1/3 & 250 \\
CK & - & 0 \\
\hline
\end{tabular}

Similar to the experimental design of Gärdenäs et al. (2005), we evaluated the effect of ten fertigation strategies on WUE, NUE, and the growth of greenhouse tomatoes. The 
experiment was conducted in a split block design consisting of 10 treatments with three replicates per treatment (i.e., 30 plots in total). Organic fertilizer (organic content $\geq 45 \%$, NPK $\geq 5 \%$, fermentation fertilizer of cattle and sheep excreta), phosphate fertilizer (triple superphosphate, $\mathrm{P}_{2} \mathrm{O}_{5} \geq 46 \%$ ), and potassium fertilizer (potassium sulfate, $\mathrm{K}_{2} \mathrm{O} \geq 51 \%$ ) were applied as the base fertilizer before transplanting tomatoes. The soil in all plots was fertilized with $1500 \mathrm{~kg} \cdot \mathrm{ha}^{-1}$ organic fertilizer, $180 \mathrm{~kg} \cdot \mathrm{ha}^{-1} \mathrm{P}_{2} \mathrm{O}_{5}$, and $120 \mathrm{~kg} \cdot \mathrm{ha}^{-1} \mathrm{~K}_{2} \mathrm{O} / \mathrm{N}$ fertilizer (urea) was applied during tomato growth. According to Zhou et al. (2020), tomato plants are sensitive to N 15 60 days after pollination; thus, $\mathrm{N}$ application within this window can improve the growth and quality of tomato. The date and amount of $\mathrm{N}$ fertilizer application are shown in Figure 4. The three levels of $\mathrm{N}$ application included 150 (N1), 200 (N2), and $250 \mathrm{~kg} \cdot \mathrm{ha}^{-1}$ (N3). The fertilizer was evenly mixed into the water flow with the hydraulic fertilizer applicator. The three injection timings (Fig. 4) were S1, wherein $\mathrm{N}$ was injected into drip line during the first $1 / 3$ of the irrigation; $\mathrm{S} 2$, wherein $\mathrm{N}$ was injected into drip line during the middle $1 / 3$ of the irrigation; and $\mathrm{S} 3$, wherein $\mathrm{N}$ was injected into drip line during the last $1 / 3$ of the irrigation. No $\mathrm{N}$ fertilizer was applied in the control group (CK).
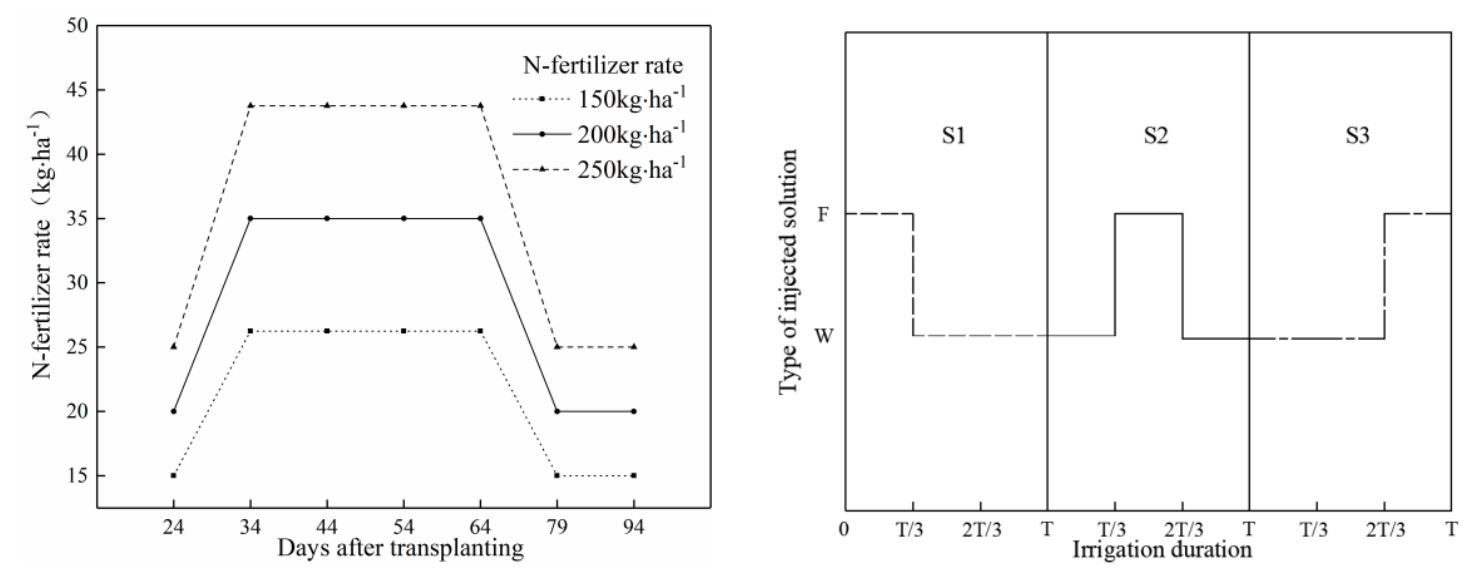

Figure 4. (a) Fertilization records over the experimental period; (b) Three timings of nitrogen injection, $T$ is irrigation duration, $F$ is urea solution, $W$ is water

\section{Sampling and measurements}

During the mature period, four tomatoes were randomly selected from each plot, and the quality of mature tomatoes was measured using an electronic scale for obtaining $Y$ per plant. The soil water content $\theta_{0}$ and $\theta_{1}$ before and after the growth period were measured by the drying method. The soil was collected at a depth of $100 \mathrm{~cm}$ and a soil interval of $20 \mathrm{~cm}$ in each plot three times. The crop ET $(\mathrm{mm})$ was calculated using the following water balance equation (Eq. 2; Allen et al., 2011):

$$
E T=P+I+U-D-R-\Delta W
$$

where $P$ is the effective precipitation $(\mathrm{mm}), I$ is the irrigation amount $\left(I=I_{1}+I_{2}, \mathrm{~mm}\right)$, $U$ is the water movement from the deep soil into the root zone $(\mathrm{mm}), D$ is the deep percolation $(\mathrm{mm}), R$ is the surface runoff $(\mathrm{mm})$, and $\Delta W$ is the change in the soil profile water content within the $0 \sim 100 \mathrm{~cm}$ soil layer $(\mathrm{mm})$, which was calculated according to Equation 3 (Allen et al., 2011): 


$$
\Delta W=1000 \times h \times\left(\theta_{0}-\theta_{1}\right)
$$

The experiment was conducted in a greenhouse with drip irrigation on flat terrain, and $I$ was small; hence, $P=0, D=0$, and $R=0$. The groundwater table was below $5.0 \mathrm{~m}$, and the crop roots were unable to absorb and utilize the groundwater. Thus, the underground water recharge was negligible, $U=0$.

The WUE was calculated by Equation 4 (Li et al., 2020):

$$
W U E=Y / E T
$$

where WUE is the crop WUE $\left(\mathrm{kg} \cdot \mathrm{m}^{-3}\right)$ and $\mathrm{Y}$ is the grain yield of crops $\left(\mathrm{kg} \cdot \mathrm{plant}^{-1}\right)$.

The NUE was calculated by Equation 5 (Nafi et al., 2019):

$$
N U E=\left(Y-Y_{c}\right) / N
$$

where $Y_{c}$ is the yield of tomato under the CK treatment in $\mathrm{kg} \cdot$ plant $^{-1}$.

The activity of several soil enzymes was determined from rhizosphere soil collected 70 days after transplantation. Three tomato plants were randomly selected in each plot, the stem of the plant was assumed as the center, and a hole was dug with a straight diameter of about $0.2 \mathrm{~m}$ and a depth of about $0.4 \mathrm{~m}$ to obtain the root system of the plant. The root was shaken to remove bulk soil, and the rhizosphere soil were collected with a sterile and soft-bristled paintbrush (Ren et al., 2021). Soil urease activity (mg $\left.\mathrm{NH}_{4}{ }^{+}-\mathrm{N}(\mathrm{g} \cdot 24 \mathrm{~h})^{-1}\right)$ was estimated using the phenol-sodium hypochlorite colorimetric method; soil sucrase activity $\left(\mu \mathrm{g}\right.$ glucose $\left.(g \cdot 24 \mathrm{~h})^{-1}\right)$ was estimated using the dinitrosalicylic acid colorimetric method; and soil phosphatase activity ( $\mu$ g nitrophenol $\left.(\mathrm{g} \cdot 24 \mathrm{~h})^{-1}\right)$ was estimated by the nitrophenylphosphate disodium colorimetric method.

In the experiment, soil was collected $64 \mathrm{~d}$ after transplantation $(5 \mathrm{~d}$ after $\mathrm{N}$ application). Soil was collected at the following depths: 0, 10, 20, 30, 40, 50, and $60 \mathrm{~cm}$. Soil was collected from a single location for each plot, which was located $5 \sim 10 \mathrm{~cm}$ away from the water dropper. The soil $\mathrm{NO}_{3}^{-}-\mathrm{N}$ content was determined by a flow analyzer (Bran + Luebbe AutoAnalyzer - III, Germany).

The instantaneous transpiration rate $\left(T_{r}\right)$ and net photosynthetic rate $\left(P_{n}\right)$ of tomato leaves in the greenhouse were measured by an LCpro-SD portable photosynthesis system (ADC, UK) (Fig. 1). Three healthy plants from each plot and three healthy leaves from each plant were selected for measurements. Measurements were taken 30, 64, and $105 \mathrm{~d}$ after transplantation. The instantaneous water use efficiency ( $\left.W U E_{L}\right)$ was calculated by Equation 6 (Zhou et al., 2020):

$$
W U E_{L}=P_{n} / T_{r}
$$

where $W U E_{L}$ is the leaf $W U E\left(\mathrm{mmol} \mathrm{CO} \cdot \mathrm{mol}^{-1} \mathrm{H}_{2} \mathrm{O}\right) ; P_{n}$ is the leaf net photosynthetic rate $\left(\mu \mathrm{mol} \mathrm{CO}_{2} \cdot \mathrm{m}^{-2} \cdot \mathrm{s}^{-1}\right)$; and $T_{r}$ is the leaf instantaneous transpiration rate (mmol $\left.\mathrm{H}_{2} \mathrm{O} \cdot \mathrm{m}^{-2} \cdot \mathrm{s}^{-1}\right)$.

\section{Data analysis}

The significant difference of SPSS22.0 (IBM Crop., Armonk, New York, NY, USA) was analyzed by $\mathrm{F}$ test, and the significant level was set to $\mathrm{P}<0.05$. 
OriginPro2019 (Origin Lab Corporation, Northampton, MA, USA) was used to draw the picture. Except for special annotations, the data are all average \pm standard deviation in the chart.

\section{Results}

\section{Distribution of $\mathrm{NO}_{3}^{-}-\mathrm{N}$}

According to Havlin et al. (2006), urea and ammonium-nitrogen $\left(\mathrm{NH}_{4}{ }^{+}-\mathrm{N}\right)$ in the soil are quickly converted into $\mathrm{NO}_{3}{ }^{-}-\mathrm{N}$. The purpose of this study was to identify the fertilization strategy that results in the most favorable nitrate distribution pattern for tomato growth by analyzing the distribution of $\mathrm{NO}_{3}{ }^{-}-\mathrm{N}($ depth of $0 \sim 60 \mathrm{~cm})$ in the soil of spring and autumn tomatoes $64 \mathrm{~d}$ after transplantation $(5 \mathrm{~d}$ after $\mathrm{N}$ fertilizer application).

Figure 5 shows variation in $\mathrm{NO}_{3}{ }^{-}-\mathrm{N}$ with soil depth under different $\mathrm{N}$ application strategies. As the soil depth increases, the $\mathrm{NO}_{3}{ }^{-} \mathrm{N}$ content first increased and then decreased, but the $\mathrm{NO}_{3}{ }^{-}-\mathrm{N}$ content peaked at different depths in the different treatments. At the same timing of $\mathrm{N}$ application, the $\mathrm{NO}_{3}{ }^{-} \mathrm{N}$ content increased as the $\mathrm{N}$ application rate increased, but there was no significant difference in the depth corresponding to the peak $\mathrm{NO}_{3}{ }^{-}-\mathrm{N}$ content among treatments. The peak values of $\mathrm{NO}_{3}{ }^{-}-\mathrm{N}$ in $\mathrm{S} 1, \mathrm{~S} 2$, and $\mathrm{S} 3$ under $\mathrm{N} 1$ were $48.46,53.38$, and $46.78 \mathrm{mg} \cdot \mathrm{kg}^{-1}$, respectively; the peak values of $\mathrm{NO}_{3}{ }^{-}-$ $\mathrm{N}$ in $\mathrm{S} 1, \mathrm{~S} 2$, and $\mathrm{S} 3$ under $\mathrm{N} 2$ were $70.15,67.22$, and $67.56 \mathrm{mg} \cdot \mathrm{kg}^{-1}$, respectively; and the peak values of $\mathrm{NO}_{3}{ }^{-} \mathrm{N}$ in $\mathrm{S} 1, \mathrm{~S} 2$, and $\mathrm{S} 3$ under $\mathrm{N} 2$ were 90.28, 89.65, and $84.97 \mathrm{mg} \cdot \mathrm{kg}^{-1}$, respectively. The depth corresponding to the peak $\mathrm{NO}_{3}{ }^{-}-\mathrm{N}$ content under different $\mathrm{N}$ application times was greatest for $\mathrm{S} 1(40 \mathrm{~cm})$, followed by $\mathrm{S} 3(30 \mathrm{~cm})$ and S2 $(20 \mathrm{~cm})$.
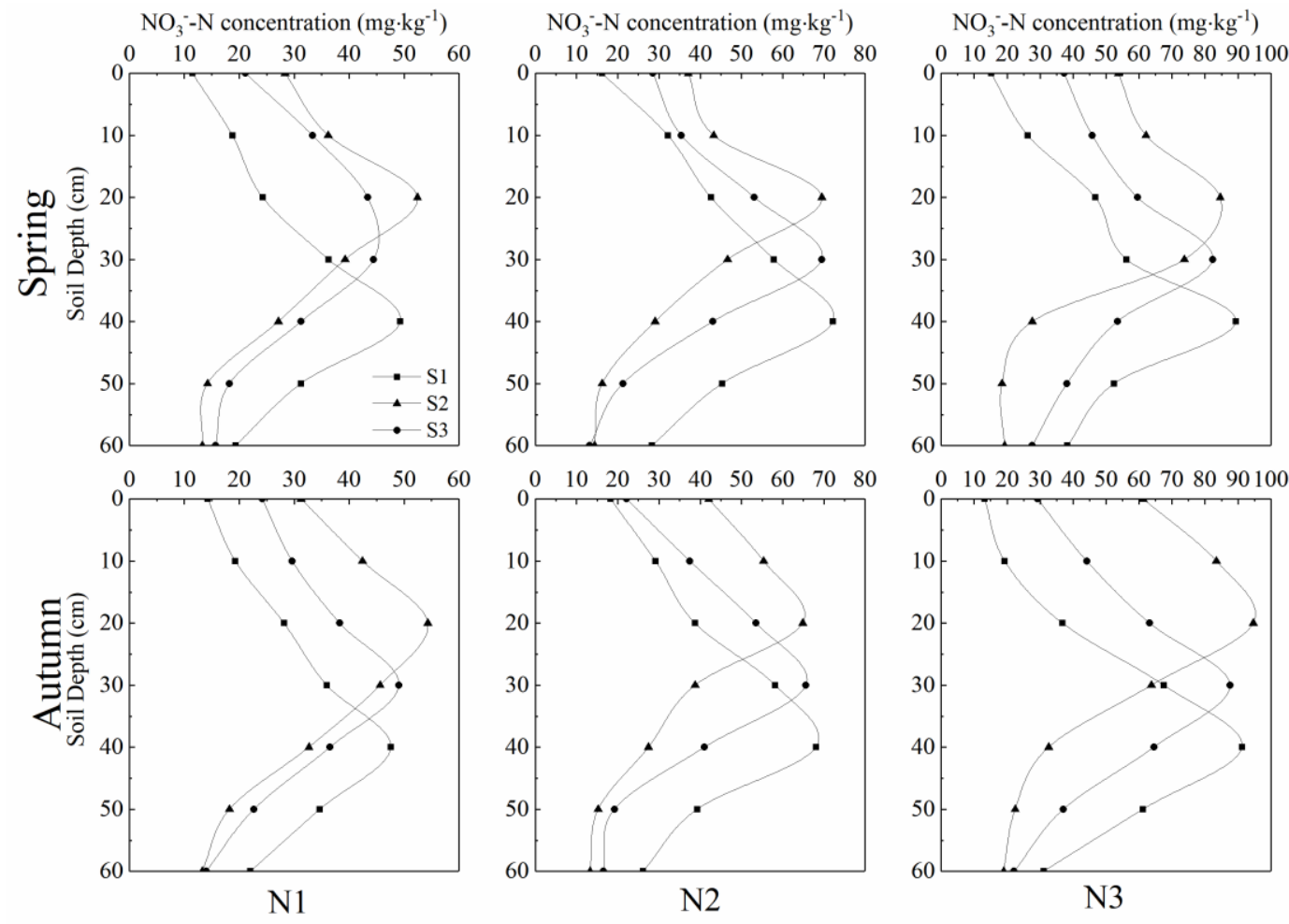

Figure 5. The distribution of $\mathrm{NO}_{3}^{-}-\mathrm{N}$ under different treatments 


\section{Photosynthetic parameters}

\section{Net photosynthetic rate}

The application rate and injection timing of $\mathrm{N}$ had significant effects on $P_{n}$, but their interaction was not significant. Table 2 shows the net photosynthetic rate of greenhouse tomatoes at each growth stage under different $\mathrm{N}$ application strategies. There were no significant differences in $P_{n}$ under the different application rate and injection timing of $\mathrm{N}$ in the W1 stage. In the W2 stage, the $P_{n}$ was significantly higher in N1, N2 and N3 than in CK. In spring and autumn tomatoes, the highest $P_{n}$ was observed in N3 (23.81 and $21.66 \mu \mathrm{mol} \mathrm{CO} \cdot \mathrm{m}^{-2} \cdot \mathrm{s}^{-1}$, respectively). Compared with $\mathrm{CK}$, the $P_{n}$ of spring and autumn tomatoes in $\mathrm{N} 3$ was increased by 38.51 and $42.22 \%$, respectively. In the W2 stage, the $P_{n}$ was significantly higher in $\mathrm{S} 1, \mathrm{~S} 2$ and $\mathrm{S} 3$ than in CK. In spring and autumn tomatoes, the highest $P_{n}$ were observed in S3 $\left(23.06\right.$ and $21.39 \mu \mathrm{mol} \mathrm{CO} 2 \cdot \mathrm{m}^{-2} \cdot \mathrm{s}^{-1}$, respectively). Compared with $\mathrm{CK}$, the $P_{n}$ of spring and autumn tomatoes in S3 was increased by 34.15 and $40.45 \%$, respectively. In the W3 stage, the $P_{n}$ was significantly higher in $\mathrm{N} 1, \mathrm{~N} 2$ and $\mathrm{N} 3$ than in $\mathrm{CK}$. The $P_{n}$ of spring and autumn tomatoes were highest for $\mathrm{N} 2\left(18.89\right.$ and $17.78 \mu \mathrm{mol} \mathrm{CO} \mathrm{CO}_{2} \cdot \mathrm{m}^{-2} \cdot \mathrm{s}^{-1}$, respectively). Compared with $\mathrm{CK}$, the $P_{n}$ of spring and autumn tomatoes in N2 was increased by 18.21 and $30.54 \%$, respectively. In the W3 stage, the $P_{n}$ was significantly higher in S1, S2 and S3 than in CK. In spring and autumn tomatoes, the highest $P_{n}$ was observed in S3 (18.67 and $17.17 \mu \mathrm{mol} \mathrm{CO} 2 \cdot \mathrm{m}^{-2} \cdot \mathrm{s}^{-1}$, respectively). Compared with CK, the $P_{n}$ of spring and autumn tomatoes in S3 were increased by 16.83 and $26.06 \%$, respectively. There were no significant differences between S2 and S3 at all stages.

Table 2. Effects of different the application rates $(N-R)$ and injection timings $(N-T)$ of $N$ on the $P_{n}\left(\mu \mathrm{mol} \mathrm{CO} \mathrm{CO}_{2} \cdot \mathrm{m}^{-2} \cdot \mathrm{s}^{-1}\right)$ of spring tomatoes and autumn tomatoes

\begin{tabular}{c|c|c|c|c|c|c}
\hline \multirow{2}{*}{$\begin{array}{c}\text { Main } \\
\text { effect }\end{array}$} & \multicolumn{3}{|c|}{ Spring } & \multicolumn{3}{c}{ Autumn } \\
\cline { 2 - 7 } & W1 & W2 & W3 & W1 & W2 & W3 \\
\hline CK & $14.76 \pm 1.71 \mathrm{aA}$ & $17.19 \pm 1.61 \mathrm{cC}$ & $15.98 \pm 1.32 \mathrm{cC}$ & $12.66 \pm 0.95 \mathrm{aA}$ & $15.23 \pm 1.52 \mathrm{cC}$ & $13.62 \pm 0.97 \mathrm{cC}$ \\
$\mathrm{N}-\mathrm{R}$ & & & & & & \\
$\mathrm{N} 1$ & $14.38 \pm 1.17 \mathrm{a}$ & $19.64 \pm 1.53 \mathrm{~b}$ & $17.08 \pm 1.24 \mathrm{~b}$ & $13.17 \pm 1.29 \mathrm{a}$ & $18.20 \pm 1.48 \mathrm{~b}$ & $15.23 \pm 1.63 \mathrm{~b}$ \\
$\mathrm{~N} 2$ & $14.86 \pm 0.98 \mathrm{a}$ & $23.16 \pm 2.24 \mathrm{a}$ & $18.89 \pm 1.41 \mathrm{a}$ & $13.16 \pm 1.40 \mathrm{a}$ & $21.71 \pm 1.57 \mathrm{a}$ & $17.78 \pm 1.37 \mathrm{a}$ \\
$\mathrm{N} 3$ & $15.02 \pm 1.11 \mathrm{a}$ & $23.81 \pm 1.92 \mathrm{a}$ & $18.47 \pm 1.27 \mathrm{a}$ & $13.16 \pm 1.37 \mathrm{a}$ & $21.66 \pm 1.85 \mathrm{a}$ & $16.94 \pm 1.28 \mathrm{a}$ \\
$\mathrm{N}-\mathrm{T}$ & & & & & & \\
$\mathrm{S} 1$ & $14.51 \pm 1.20 \mathrm{~A}$ & $20.59 \pm 2.13 \mathrm{~B}$ & $17.51 \pm 1.32 \mathrm{~B}$ & $13.13 \pm 1.30 \mathrm{~A}$ & $19.30 \pm 2.35 \mathrm{~B}$ & $15.75 \pm 1.65 \mathrm{~B}$ \\
$\mathrm{~S} 2$ & $14.98 \pm 1.10 \mathrm{~A}$ & $22.96 \pm 2.75 \mathrm{~A}$ & $18.26 \pm 1.36 \mathrm{AB}$ & $13.22 \pm 1.36 \mathrm{~A}$ & $20.88 \pm 2.17 \mathrm{~A}$ & $17.04 \pm 1.59 \mathrm{~A}$ \\
$\mathrm{~S} 3$ & $14.77 \pm 1.01 \mathrm{~A}$ & $23.06 \pm 2.31 \mathrm{~A}$ & $18.67 \pm 1.65 \mathrm{~A}$ & $13.35 \pm 1.40 \mathrm{~A}$ & $21.39 \pm 1.95 \mathrm{~A}$ & $17.17 \pm 1.77 \mathrm{~A}$ \\
\hline F-value & & & & & & \\
$\mathrm{N}$ & $2.16 \mathrm{~ns}$ & $57.33^{* *}$ & $15.71 * *$ & $0.21 \mathrm{~ns}$ & $54.09 * *$ & $27.38^{* *}$ \\
$\mathrm{~S}$ & $1.10 \mathrm{~ns}$ & $22.25 * *$ & $6.01 * *$ & $0.19 \mathrm{~ns}$ & $15.85^{* *}$ & $9.97 * *$ \\
$\mathrm{~N} * \mathrm{~S}$ & $0.48 \mathrm{~ns}$ & $1.19 \mathrm{~ns}$ & $0.76 \mathrm{~ns}$ & $0.79 \mathrm{~ns}$ & $0.36 \mathrm{~ns}$ & $0.32 \mathrm{~ns}$ \\
\hline
\end{tabular}

The data are all average \pm standard deviation in the figure, different letters in the same column meant significant difference at 0.05 level, lowercase letters indicate differences between $\mathrm{N}$ application rates, capital letters indicate differences between $\mathrm{N}$ injection timings; * indicates significant correlation $(\mathrm{P}<0.05)$; ** indicates highly significant correlation $(\mathrm{P}<0.01)$, and ns indicates not significant 
$W U E_{L}$

Table 3 shows the instantaneous water use efficiency ( $W U E_{L}$, calculated by $E q .6$ ) of greenhouse tomatoes at each growth stage under different $\mathrm{N}$ application strategies. There were no significant differences in $W U E_{L}$ among the different treatments in the $\mathrm{W} 1$ stage. In the $\mathrm{W} 2$ stage, the $W U E_{L}$ first increased and then decreased as the $\mathrm{N}$ application rate increased. The $W U E_{L}$ of spring and autumn tomatoes were highest for $\mathrm{N} 2$ (2.25 and $2.43 \mathrm{mmol} \mathrm{CO} \cdot \mathrm{mol}^{-1} \mathrm{H}_{2} \mathrm{O}$, respectively). Compared with $\mathrm{CK}$, the $W U E_{L}$ was increased by $25.70 \%$ and $48.17 \%$ in $\mathrm{N} 2$ for spring and autumn tomatoes, respectively. In the $\mathrm{W} 2$ stage, the $W U E_{L}$ was significantly higher in $\mathrm{S} 1, \mathrm{~S} 2$ and $\mathrm{S} 3$ than in CK. In spring and autumn tomatoes, the highest $W U E_{L}$ were observed in S3 (2.21 and $2.36 \mathrm{mmol} \mathrm{CO} 2 \cdot \mathrm{mol}^{-1} \mathrm{H}_{2} \mathrm{O}$, respectively). Compared with $\mathrm{CK}$, the $W U E_{L}$ of spring and autumn tomatoes in S3 was increased by 23.46 and $43.90 \%$, respectively. In the W3 stage, the $\mathrm{WUE}_{\mathrm{L}}$ first increased and then decreased as the $\mathrm{N}$ application rate increased. The $W U E_{L}$ of spring and autumn tomatoes were highest for $\mathrm{N} 2$ (2.33 and $2.49 \mathrm{mmol}$ $\mathrm{CO}_{2} \cdot \mathrm{mol}^{-1} \mathrm{H}_{2} \mathrm{O}$, respectively). Compared with $\mathrm{CK}$, the $W U E_{L}$ was increased by $24.60 \%$ and $31.75 \%$ in $\mathrm{N} 2$ for spring and autumn tomatoes, respectively. In the W3 stage, the $W U E_{L}$ was significantly higher in $\mathrm{S} 1, \mathrm{~S} 2$ and $\mathrm{S} 3$ than in CK. In the W3 stage, the $W U E_{L}$ for spring tomatoes was highest in $\mathrm{S} 3\left(2.30 \mathrm{mmol} \mathrm{CO} \cdot \mathrm{mol}^{-1} \mathrm{H}_{2} \mathrm{O}\right)$, and that for autumn tomatoes was highest in S2 $\left(2.43 \mathrm{mmol} \mathrm{CO}{ }_{2} \cdot \mathrm{mol}^{-1} \mathrm{H}_{2} \mathrm{O}\right)$. Compared with $\mathrm{CK}$, the $W U E_{L}$ was increased by $24.60 \%$ and $31.75 \%$ in $\mathrm{N} 2$ for spring and autumn tomatoes, respectively. In the $\mathrm{W} 3$ stage, the $W U E_{L}$ was significantly higher in $\mathrm{S} 1, \mathrm{~S} 2$ and $\mathrm{S} 3$ than in CK. In the W3 stage, the $W U E_{L}$ for spring tomatoes was highest in S3 $(2.30 \mathrm{mmol}$ $\left.\mathrm{CO}_{2} \cdot \mathrm{mol}^{-1} \mathrm{H}_{2} \mathrm{O}\right)$, and that for autumn tomatoes was highest in $\mathrm{S} 2\left(2.43 \mathrm{mmol} \mathrm{CO} \cdot \mathrm{mol}^{-1}\right.$ $\mathrm{H}_{2} \mathrm{O}$ ). Compared with CK, the $W U E_{L}$ was increased by $22.99 \%$ in $\mathrm{S} 3$ and $28.57 \%$ in $\mathrm{S} 2$ for spring and autumn tomatoes, respectively.

Table 3. Effects of different the application rates $(N-R)$ and injection timings $(N-T)$ on the $W_{U} E_{L}\left(\mathrm{mmol} \mathrm{CO}_{2} \cdot \mathrm{mol}^{-1} \mathrm{H}_{2} \mathrm{O}\right)$ of spring tomatoes and autumn tomatoes

\begin{tabular}{c|c|c|c|c|c|c}
\hline \multirow{2}{*}{$\begin{array}{c}\text { Main } \\
\text { effect }\end{array}$} & \multicolumn{3}{|c|}{ Spring } & \multicolumn{3}{c}{ Autumn } \\
\cline { 2 - 7 } $\mathrm{CK}$ & $2.12 \pm 0.24 \mathrm{aA}$ & $1.79 \pm 0.27 \mathrm{cB}$ & $1.87 \pm 0.17 \mathrm{cB}$ & $1.87 \pm 0.17 \mathrm{aA}$ & $1.64 \pm 0.16 \mathrm{cC}$ & $1.89 \pm 0.09 \mathrm{cC}$ \\
$\mathrm{N}-\mathrm{R}$ & & & & & & \\
$\mathrm{N} 1$ & $2.01 \pm 0.19 \mathrm{a}$ & $1.97 \pm 0.22 \mathrm{~b}$ & $2.11 \pm 0.23 \mathrm{~b}$ & $2.13 \pm 0.21 \mathrm{a}$ & $2.04 \pm 0.18 \mathrm{~b}$ & $2.18 \pm 0.18 \mathrm{~b}$ \\
$\mathrm{~N} 2$ & $2.10 \pm 0.17 \mathrm{a}$ & $2.25 \pm 0.34 \mathrm{a}$ & $2.33 \pm 0.21 \mathrm{a}$ & $2.36 \pm 0.19 \mathrm{a}$ & $2.43 \pm 0.21 \mathrm{a}$ & $2.49 \pm 0.22 \mathrm{a}$ \\
$\mathrm{N} 3$ & $2.15 \pm 0.24 \mathrm{a}$ & $2.23 \pm 0.21 \mathrm{a}$ & $2.23 \pm 0.29 \mathrm{ab}$ & $2.26 \pm 0.30 \mathrm{a}$ & $2.35 \pm 0.22 \mathrm{a}$ & $2.40 \pm 0.17 \mathrm{a}$ \\
$\mathrm{N}-\mathrm{T}$ & & & & & & \\
$\mathrm{S} 1$ & $2.04 \pm 0.22 \mathrm{~A}$ & $2.05 \pm 0.25 \mathrm{~A}$ & $2.12 \pm 0.23 \mathrm{~A}$ & $2.20 \pm 0.25 \mathrm{~A}$ & $2.16 \pm 0.25 \mathrm{~B}$ & $2.24 \pm 0.22 \mathrm{~B}$ \\
$\mathrm{~S} 2$ & $2.14 \pm 0.19 \mathrm{~A}$ & $2.19 \pm 0.31 \mathrm{~A}$ & $2.25 \pm 0.27 \mathrm{~A}$ & $2.25 \pm 0.27 \mathrm{~A}$ & $2.30 \pm 0.25 \mathrm{~A}$ & $2.43 \pm 0.22 \mathrm{~A}$ \\
$\mathrm{~S} 3$ & $2.08 \pm 0.21 \mathrm{~A}$ & $2.21 \pm 0.29 \mathrm{~A}$ & $2.30 \pm 0.25 \mathrm{~A}$ & $2.30 \pm 0.25 \mathrm{~A}$ & $2.36 \pm 0.25 \mathrm{~A}$ & $2.41 \pm 0.20 \mathrm{~A}$ \\
\hline $\mathrm{F}-\mathrm{value}$ & & & & & & \\
$\mathrm{N}$ & $3.09 \mathrm{~ns}$ & $10.26^{* *}$ & $6.24^{* *}$ & $1.51 \mathrm{~ns}$ & $33.93^{* *}$ & $24.05^{* *}$ \\
$\mathrm{~S}$ & $1.63 \mathrm{~ns}$ & $2.94^{*}$ & $4.15^{*}$ & $1.87 \mathrm{~ns}$ & $8.50^{* *}$ & $10.67^{* *}$ \\
$\mathrm{~N} * \mathrm{~S}$ & $0.43 \mathrm{~ns}$ & $1.48 \mathrm{~ns}$ & $1.00 \mathrm{~ns}$ & $1.18 \mathrm{~ns}$ & $1.03 \mathrm{~ns}$ & $0.51 \mathrm{~ns}$ \\
\hline
\end{tabular}

The data are all average \pm standard deviation in the figure, different letters in the same column meant significant difference at 0.05 level, lowercase letters indicate differences between $\mathrm{N}$ application rates, capital letters indicate differences between $\mathrm{N}$ injection timings; * indicates significant correlation $(\mathrm{P}<0.05)$; ** indicates highly significant correlation $(\mathrm{P}<0.01)$, and ns indicates not significant 


$$
-3249 \text { - }
$$

\section{Rhizosphere soil enzyme activity}

The application rate and injection timing of $\mathrm{N}$ had significant effects on soil urease activity, but their interaction was not significant (Table 4). Therefore, these two factors were analyzed separately. Soil urease activity increased as the $\mathrm{N}$ application rate increased, but there was no significant difference between $\mathrm{N} 2$ and N3. The soil urease activity of spring and autumn tomatoes was the highest in $\mathrm{N} 3$, which was 0.74 and $0.67 \mathrm{mg} \cdot(\mathrm{g} \cdot 24 \mathrm{~h})^{-1}$, respectively. Compared with $\mathrm{CK}$, the soil urease activity was increased by 29.82 and $31.37 \%$ in spring and autumn tomatoes under N3, respectively. Soil urease activity was higher under $\mathrm{S} 2$ and $\mathrm{S} 3$ than under $\mathrm{S} 1$, but there was no significant difference between S2 and S3. The soil urease activity of spring and autumn tomatoes was the highest in S3, which was 0.73 and $0.65 \mathrm{mg} \cdot(\mathrm{g} \cdot 24 \mathrm{~h})^{-1}$, respectively. Compared with CK, the soil urease activity was increased by 28.07 and $27.45 \%$ in spring and autumn tomatoes under S3, respectively.

Table 4. Effects of different application rates $(N-R)$ and injection timings $(N-T)$ on rhizosphere soil urease activity

\begin{tabular}{c|c|c}
\hline \multirow{2}{*}{ Main effect } & \multicolumn{2}{|c}{ Soil urease $\mathbf{~ m} \cdot(\mathbf{g} \cdot \mathbf{2 4} \mathbf{~ h})^{-\mathbf{1}}$} \\
\cline { 2 - 3 } & Spring & Autumn \\
\hline CK & $0.57 \pm 0.04 \mathrm{cC}$ & $0.51 \pm 0.06 \mathrm{cC}$ \\
N-R & $0.65 \pm 0.06 \mathrm{~b}$ & $0.59 \pm 0.07 \mathrm{~b}$ \\
N1 & $0.71 \pm 0.06 \mathrm{a}$ & $0.64 \pm 0.06 \mathrm{a}$ \\
N2 & $0.74 \pm 0.08 \mathrm{a}$ & $0.67 \pm 0.07 \mathrm{a}$ \\
N3 & & \\
N-T & $0.66 \pm 0.07 \mathrm{~B}$ & $0.60 \pm 0.07 \mathrm{~B}$ \\
S1 & $0.71 \pm 0.07 \mathrm{~A}$ & $0.64 \pm 0.07 \mathrm{AB}$ \\
S2 & $0.73 \pm 0.08 \mathrm{~A}$ & $0.65 \pm 0.06 \mathrm{~A}$ \\
S3 & & \\
F-value & $14.16^{* *}$ & $9.59^{* *}$ \\
N & $7.75^{* *}$ & $4.85^{*}$ \\
S & $0.34 \mathrm{~ns}$ & $0.15 \mathrm{~ns}$ \\
N*S &
\end{tabular}

The data are all average \pm standard deviation in the figure, different letters in the same column meant significant difference at 0.05 level, lowercase letters indicate differences between $\mathrm{N}$ application rates, capital letters indicate differences between $\mathrm{N}$ injection timings; * indicates significant correlation $(\mathrm{P}<0.05)$; ** indicates highly significant correlation $(\mathrm{P}<0.01)$, and ns indicates not significant

The application rate and injection timing of $\mathrm{N}$ had significant interaction effects on soil sucrase activity (Table 5). Under $\mathrm{S} 1$, soil sucrase activity increased as the $\mathrm{N}$ application rate increased. Under S2 and S3, soil sucrase activity first increased and then decreased as the $\mathrm{N}$ application rate increased. At the same $\mathrm{N}$ application rate, soil sucrase activity was significantly higher under S2 and S3 than under S1, but there was no significant difference between S2 and S3. The soil sucrase activity of spring and autumn tomatoes was the highest under N2S2 $\left(4.42\right.$ and $3.74 \mu \mathrm{g} \cdot(\mathrm{g} \cdot 24 \mathrm{~h})^{-1}$, respectively). Compared with $\mathrm{CK}$, the soil sucrase activity was increased by 75.4 and $79.81 \%$ in spring and autumn tomatoes under N2S2, respectively. 
The application rate and injection timing of $\mathrm{N}$ had significant interaction effects on soil phosphatase activity (Table 5). Under S1, soil phosphatase activity increased as the $\mathrm{N}$ application rate increased, but there was no significant difference between N2S1 and N3S1. Under S2 and S3, soil acid phosphatase activity first increased and then decreased as the $\mathrm{N}$ application rate increased. At the same $\mathrm{N}$ application rate, soil phosphatase activity was significantly higher under S2 and S3 than under S1, but there was no significant difference between S2 and S3. Soil phosphatase activity was highest in spring tomatoes under $\mathrm{N} 2 \mathrm{~S} 3$ and in autumn tomatoes under N2S2 (33.25 and $25.57 \mu \mathrm{g} \cdot(\mathrm{g} \cdot 24 \mathrm{~h})^{-1}$, respectively). Compared with CK, the soil phosphatase activity was increased by 64.44 and $97.45 \%$ in spring tomato under N2S3 and autumn tomato under N2S2, respectively.

Table 5. Effects of different treatments on rhizosphere soil sucrase and phosphatase activity

\begin{tabular}{|c|c|c|c|c|}
\hline \multirow[b]{2}{*}{ Treatment } & \multicolumn{2}{|c|}{ Spring } & \multicolumn{2}{|c|}{ Autumn } \\
\hline & $\begin{array}{l}\text { Soil sucrase } \\
\mu \mathrm{g} \cdot(\mathrm{g} \cdot 24 \mathrm{~h})^{-1}\end{array}$ & $\begin{array}{c}\text { Soil phosphatase } \\
\mu \mathrm{g} \cdot(\mathrm{g} \cdot 24 \mathrm{~h})^{-1}\end{array}$ & $\begin{array}{l}\text { Soil sucrase } \\
\mu \mathrm{g} \cdot(\mathrm{g} \cdot 24 \mathrm{~h})^{-1}\end{array}$ & $\begin{array}{c}\text { Soil phosphatase } \\
\mu \mathrm{g} \cdot(\mathrm{g} \cdot 24 \mathrm{~h})^{-1}\end{array}$ \\
\hline N1S1 & $3.02 \pm 0.51 \mathrm{c}$ & $22.67 \pm 2.38 \mathrm{e}$ & $2.53 \pm 0.19 \mathrm{~d}$ & $14.3 \pm 1.39 f$ \\
\hline N1S2 & $3.31 \pm 0.19 c$ & $24.74 \pm 2.02 \mathrm{e}$ & $2.93 \pm 0.22 c$ & $16.84 \pm 1.43 \mathrm{de}$ \\
\hline N1S3 & $3.31 \pm 0.13 c$ & $24.82 \pm 1.59 \mathrm{~d}$ & $2.94 \pm 0.25 c$ & $16.73 \pm 1.91 \mathrm{e}$ \\
\hline $\mathrm{N} 2 \mathrm{~S} 1$ & $3.73 \pm 0.28 b$ & $27.2 \pm 1.14 \mathrm{c}$ & $3.26 \pm 0.21 b$ & $18.22 \pm 1.62 \mathrm{~cd}$ \\
\hline $\mathrm{N} 2 \mathrm{~S} 2$ & $4.42 \pm 0.24 \mathrm{a}$ & $33.17 \pm 2.04 \mathrm{a}$ & $3.74 \pm 0.24 \mathrm{a}$ & $25.57 \pm 1.51 \mathrm{a}$ \\
\hline $\mathrm{N} 2 \mathrm{~S} 3$ & $4.34 \pm 0.19 \mathrm{a}$ & $33.25 \pm 1.92 \mathrm{a}$ & $3.61 \pm 0.33 \mathrm{a}$ & $24.95 \pm 1.51 \mathrm{a}$ \\
\hline N3S1 & $3.9 \pm 0.36 b$ & $28.99 \pm 1.76 b$ & $3.28 \pm 0.23 b$ & $18.82 \pm 1.44 b c$ \\
\hline $\mathrm{N} 3 \mathrm{~S} 2$ & $3.96 \pm 0.5 b$ & $29.97 \pm 1.57 b$ & $3.31 \pm 0.2 b$ & $19.93 \pm 1.63 b$ \\
\hline N3S3 & $3.94 \pm 0.22 b$ & $29.88 \pm 2.62 b$ & $3.3 \pm 0.18 b$ & $19.89 \pm 1.42 b$ \\
\hline $\mathrm{CK}$ & $2.52 \pm 0.31 \mathrm{~d}$ & $20.22 \pm 1.28 \mathrm{f}$ & $2.08 \pm 0.21 \mathrm{e}$ & $12.95 \pm 0.73 f$ \\
\hline \multicolumn{5}{|l|}{ F-value } \\
\hline $\mathrm{N}$ & $65.46 * *$ & $106.60 * *$ & $73.19 * *$ & $149.35^{* *}$ \\
\hline $\mathrm{S}$ & $9.75^{* *}$ & $23.14 * *$ & $13.53 * *$ & $71.18 * *$ \\
\hline $\mathrm{N} * \mathrm{~S}$ & $2.72 *$ & $5.99 * *$ & $3.07 *$ & $10.66 * *$ \\
\hline
\end{tabular}

The data are all average \pm standard deviation in the figure, different letters in the same column meant significant difference at 0.05 level, lowercase letters indicate differences between $\mathrm{N}$ application rates, capital letters indicate differences between $\mathrm{N}$ injection timings; * indicates significant correlation $(\mathrm{P}<0.05)$; ** indicates highly significant correlation $(\mathrm{P}<0.01)$, and ns indicates not significant

\section{$Y, W U E$, and NUE}

The application rate and injection timing of $\mathrm{N}$ had significant effects on spring and autumn tomato $Y, W U E$ (calculated by Eq. 4), and NUE (calculated by Eq. 5; Table 6). As no interaction effects were detected, the two factors were analyzed separately. The $Y$ of spring and autumn tomatoes increased as the $\mathrm{N}$ application rate increased. The $Y$ was significantly higher under N1, N2 and N3 than under CK, but there was no significant difference between $\mathrm{N} 2$ and $\mathrm{N} 3$. The $\mathrm{Y}$ of spring and autumn tomatoes was the highest in $\mathrm{N} 3$, which was 2.75 and $2.39 \mathrm{~kg} \cdot$ plant $^{-1}$, respectively. Compared with $\mathrm{CK}$, the $\mathrm{Y}$ was increased by 55.37 and $52.23 \%$ in spring and autumn tomatoes under N3, respectively. The $Y$ was higher in $\mathrm{S} 1, \mathrm{~S} 2$ and $\mathrm{S} 3$ than under $\mathrm{S} 1$, but there was no significant difference between $\mathrm{S} 2$ and $\mathrm{S} 3$. The $\mathrm{Y}$ for spring tomatoes was highest in S3 
$\left(2.62 \mathrm{~kg} \cdot \mathrm{plant}^{-1}\right)$, and that for autumn tomatoes was highest in $\mathrm{S} 2\left(2.29 \mathrm{~kg} \cdot \mathrm{plant}^{-1}\right)$. Compared with CK, the $Y$ was increased by 48.02 and $45.86 \%$ in spring and autumn tomatoes under $\mathrm{S} 3$ and $\mathrm{S} 2$, respectively. The variation in $W U E$ was similar to that observed for $Y$. The $\mathrm{Y}$ of spring and autumn tomatoes increased as the $\mathrm{N}$ application rate increased. The $W U E$ of spring and autumn tomatoes was highest under N3, which was 21.18 and $26.64 \mathrm{~kg} \cdot \mathrm{m}^{-3}$, respectively. Compared with $\mathrm{CK}$, the $W U E$ was increased by 49.58 and $47.18 \%$ in spring and autumn tomatoes under $\mathrm{N} 3$, respectively. The WUE was higher in S1, S2 and S3 than under S1, but there was no significant difference between $\mathrm{S} 2$ and S3. The WUE for spring and autumn tomatoes was highest in S3 (20.24 and $25.61 \mathrm{~kg} \cdot \mathrm{m}^{-3}$, respectively). Compared with $\mathrm{CK}$, the $W U E$ was increased by 42.94 and $41.49 \%$ in spring and autumn tomatoes under S3, respectively. NUE first increased and then decreased as the $\mathrm{N}$ application rate increased. $N U E$ was highest under N2. Compared with N1, the NUE was increased by 52.19 and $31.43 \%$ in spring and autumn tomatoes under $\mathrm{N} 2$, respectively. The $N U E$ for spring tomatoes was highest in $\mathrm{S} 3\left(122.22 \mathrm{~kg} \cdot \mathrm{kg}^{-1}\right)$, and that for autumn tomatoes was highest in $\mathrm{S} 2\left(105.59 \mathrm{~kg} \cdot \mathrm{kg}^{-}\right.$ ${ }^{1}$ ). Compared to $\mathrm{S} 1$, the $N U E$ was increased by 53.70 and $31.87 \%$ in spring and autumn tomatoes under $\mathrm{S} 3$ and $\mathrm{S} 2$, respectively.

Table 6. Effects of different the application rates $(N-R)$ and injection timings $(N-T)$ on the $Y$, WUE, and NUE of spring tomatoes and autumn tomatoes

\begin{tabular}{|c|c|c|c|c|c|c|}
\hline \multirow[b]{2}{*}{$\begin{array}{l}\text { Main } \\
\text { effect }\end{array}$} & \multicolumn{3}{|c|}{ Spring } & \multicolumn{3}{|c|}{ Autumn } \\
\hline & $\begin{array}{c}W U E \\
\left(\mathbf{k g} \cdot \mathbf{m}^{-3}\right)\end{array}$ & $\begin{array}{c}N U E \\
\left(\mathbf{k g} \cdot \mathbf{k g}^{-1}\right)\end{array}$ & $\begin{array}{c}Y \\
\left(\mathrm{~kg} \cdot \text { plant }^{-1}\right)\end{array}$ & $\begin{array}{c}W U E \\
\left(\mathbf{k g} \cdot \mathbf{m}^{-3}\right)\end{array}$ & $\begin{array}{c}N U E \\
\left(\mathbf{k g} \cdot \mathbf{k g}^{-1}\right)\end{array}$ & $\begin{array}{c}Y \\
\left(\mathrm{~kg} \cdot \text { plant }^{-1}\right) \\
\end{array}$ \\
\hline $\mathrm{CK}$ & $14.16 \pm 1.26 \mathrm{dC}$ & - & $1.77 \pm 0.16 \mathrm{dC}$ & $18.10 \pm 1.54 \mathrm{cC}$ & - & $1.57 \pm 0.13 \mathrm{cC}$ \\
\hline $\mathrm{N}-\mathrm{R}$ & & & & & & \\
\hline 150 & $17.17 \pm 1.20 \mathrm{c}$ & $81.48 \pm 31.96 b$ & $2.19 \pm 0.16 \mathrm{c}$ & $22.75 \pm 1.98 b$ & $83.33 \pm 34.50 \mathrm{~b}$ & $1.99 \pm 0.18 b$ \\
\hline 200 & $20.30 \pm 1.71 b$ & $123.96 \pm 33.70 \mathrm{a}$ & $2.61 \pm 0.23 \mathrm{~b}$ & $25.45 \pm 1.95 \mathrm{a}$ & $109.52 \pm 25.81 \mathrm{a}$ & $2.32 \pm 0.18 \mathrm{a}$ \\
\hline 250 & $21.18 \pm 1.56 \mathrm{a}$ & $115.67 \pm 26.26 \mathrm{a}$ & $2.75 \pm 0.21 \mathrm{a}$ & $26.64 \pm 2.16 \mathrm{a}$ & $95.85 \pm 22.67 \mathrm{ab}$ & $2.39 \pm 0.19 \mathrm{a}$ \\
\hline $\mathrm{N}-\mathrm{T}$ & & & & & & \\
\hline S1 & $18.32 \pm 2.01 \mathrm{~B}$ & $79.52 \pm 29.04 \mathrm{~B}$ & $2.34 \pm 0.27 \mathrm{~B}$ & $23.72 \pm 1.98 \mathrm{~B}$ & $80.07 \pm 22.36 \mathrm{~B}$ & $2.12 \pm 0.20 \mathrm{~B}$ \\
\hline S2 & $20.09 \pm 2.12 \mathrm{~A}$ & $119.37 \pm 29.37 \mathrm{~A}$ & $2.60 \pm 0.29 \mathrm{~A}$ & $25.49 \pm 2.32 \mathrm{~A}$ & $105.59 \pm 26.75 \mathrm{~A}$ & $2.29 \pm 0.22 \mathrm{~A}$ \\
\hline S3 & $20.24 \pm 2.26 \mathrm{~A}$ & $122.22 \pm 30.96 \mathrm{~A}$ & $2.62 \pm 0.31 \mathrm{~A}$ & $25.61 \pm 3.00 \mathrm{~A}$ & $103.04 \pm 33.19 \mathrm{~A}$ & $2.29 \pm 0.28 \mathrm{~A}$ \\
\hline F-value & & & & & & \\
\hline $\mathrm{N}$ & $73.62 * *$ & $20.80^{* *}$ & $89.92 * *$ & $32.11 * *$ & $6.75 * *$ & $43.72^{* *}$ \\
\hline$S$ & $17.59^{* *}$ & $24.04 * *$ & $25.98^{* *}$ & $9.06 * *$ & $7.77 * *$ & $9.37 * *$ \\
\hline $\mathrm{N} * \mathrm{~S}$ & $0.975 \mathrm{~ns}$ & $0.78 \mathrm{~ns}$ & $1.21 \mathrm{~ns}$ & $0.91 \mathrm{~ns}$ & $0.56 \mathrm{~ns}$ & $0.77 \mathrm{~ns}$ \\
\hline
\end{tabular}

The data are all average \pm standard deviation in the figure, different letters in the same column meant significant difference at 0.05 level, lowercase letters indicate differences between $\mathrm{N}$ application rates, capital letters indicate differences between $\mathrm{N}$ injection timings; * indicates significant correlation $(\mathrm{P}<0.05)$; ** indicates highly significant correlation $(\mathrm{P}<0.01)$, and ns indicates not significant

\section{Discussion}

\section{Effects of the rate and timing of $N$ application on photosynthetic characteristics}

In this study, the $P_{n}$ of greenhouse tomatoes under different treatments differed in different growth stages. In the W1 stage, the application rate and injection timing of $\mathrm{N}$ had little effect on the $P_{n}$ of greenhouse tomato. This may stem from the fact that 
tomato plants were small and have a low demand for $\mathrm{N}$, and the $\mathrm{N}$ level in all treatments was sufficient for meeting the growth demands of the tomato plants. In the W2 stage, the $P_{n}$ of greenhouse tomatoes increased as the $\mathrm{N}$ application rate increased; this finding is consistent with those of Ruiz et al. (2008). There was no significant difference in the $P_{n}$ between N3 and N2. The $P_{n}$ was higher under S2 and S3 than under S1, which stems from the fact that the distribution of $\mathrm{N}$ under $\mathrm{S} 2$ and $\mathrm{S} 3$ was more conducive to the absorption and utilization of $\mathrm{N}$ by tomato plants. In the W3 stage, the $P_{n}$ of greenhouse tomatoes first increased and then decreased as the $\mathrm{N}$ application rate increased. Previous studies (Wang et al., 2018; Huang et al., 2003) have shown that greater applications of fertilizer in the early and middle stages of tomato growth may lead to the overgrowth of tomato plants, resulting in shortages of water and fertilizer in the late growth stage. Variation in the $P_{n}$ among different $\mathrm{N}$ application timings in the $\mathrm{W} 1$ stage was similar to that in the W2 stage. In the W3 stage, variation in the $P_{n}$ under different $\mathrm{N}$ application timings was similar to that in the W2 stage.

$W U E_{L}$ is an important parameter used to describe $W U E$ at the leaf scale (Centritto et al., 2000). The variation in $W U E_{L}$ of greenhouse tomatoes under different treatments in this study differed among growth stages. In the W1 stage, there was no significant difference in the $W U E_{L}$ of greenhouse tomatoes under different treatments. In the W2 and $\mathrm{W} 3$ stages, the $W U E_{L}$ first increased and then decreased as the $\mathrm{N}$ application rate increased. This indicates that an appropriate $\mathrm{N}$ application rate (i.e., not too high or low) can improve tomato $W U E_{L}$, a finding that is consistent with those of Zhou et al. (2020).

\section{Effects of the rate and timing of $N$ application on soil enzyme activities}

Soil enzymes are derived from the secretions of animals, plants, and microbial cells and their decomposed residues in soil, and microbial cells are the main source of soil enzymes. There is a close correlation between soil enzyme activities and soil physicochemical properties (Acosta et al., 1999). In general, high enzyme activity is considered an important indicator of soil fertility (Hussain et al., 2017). There were significant differences in soil enzyme activities between all treatments (Tables 4 and 5). The soil enzyme activity was higher in spring tomatoes than in autumn tomatoes. This mainly stems from the fact that the soil temperature was higher for spring tomatoes than for autumn tomatoes. Lower temperature reduces cell activity, which is not conducive to the respiration of microorganisms and crops (Luo et al., 2020), and thus affects the activity of soil enzymes.

Soil urease catalyzes the hydrolysis of urea to $\mathrm{NH}_{3}$ (Ibrahim et al., 2020). As the $\mathrm{N}$ application rate increased, the soil urease activity increased, and the soil urease activity was significantly higher under N2 and N3 than under N1. Previous studies have shown that the response of soil urease activity to increases in $\mathrm{N}$ varies in different ecosystems. For example, some studies have shown that soil urease activity significantly increases when the $\mathrm{N}$ fertilizer applied increases (Dalal et al., 1975; Wang et al., 2008). By contrast, other studies have shown that increases in $\mathrm{N}$ application can inhibit soil urease activity (Wang et al., 2014; Khakural et al., 1995). This is because (1) soil microbial activity is not exclusively dependent on the total soil $\mathrm{N}$ content but is also restricted by the soil organic carbon content and (2) soil types, vegetation types, and nutrient availability vary in different ecosystems. In this paper, the application of organic fertilizer before planting tomato increased the soil organic carbon content; consequently, the increased application of $\mathrm{N}$ fertilizer increased soil urease activity, which was consistent with the results of Marcote et al. (2001) and Liu et al. (2010). 
There was no significant difference in urease activity between $\mathrm{N} 2$ and N3. The excessive accumulation of $\mathrm{NH}_{4}{ }^{+}-\mathrm{N}$ in the soil as the $\mathrm{N}$ application rate increased is thought to inhibit soil urease activity. Given that an $\mathrm{N}$ application rate of $250 \mathrm{~kg} \cdot \mathrm{ha}^{-1}$ was not sufficient for inhibiting soil urease activity, additional work is needed to determine whether there is eventually an $\mathrm{N}$ application rate beyond which soil urease activity is reduced. Compared with $\mathrm{S} 1$, the urease activity under S2 and S3 was significantly increased, which mainly stemmed from the difference in the timing of $\mathrm{N}$ application and $\mathrm{N}$ distribution in the soil (Fig. 5).

Soil sucrase is directly involved in the metabolism of organic matter and the release of low molecular weight sugars in soil, which is an important index for characterizing the rate of soil carbon cycling. There were significant differences in soil sucrase activity under different $\mathrm{N}$ application rates (Table 5). Compared with the control group, the application of $\mathrm{N}$ fertilizer increased the activity of sucrase, and as the $\mathrm{N}$ application rate increased, the soil sucrase activity first increased and then decreased. This may stem from the fact that as the $\mathrm{N}$ application rate increases, soil organic carbon content gradually becomes the main factor restricting soil microbial activity. According to Kim et al. (2011), when the background value of soil N content is high, the increase in $\mathrm{N}$ application tends to inhibit enzyme activity; in all other cases, soil $\mathrm{N}$ content improves enzyme activity, and the results of this paper confirm this observation. Soil sucrase activity under S2 and S3 was significantly different from that under S1, which may stem from the fact that the different distributions of $\mathrm{N}$ among treatments affected the intensity of the activity of microorganisms near plant roots and soil sucrase activity.

The secretion of soil phosphatase is an important adaptive response of plants to low P environments (Taylor et al., 1993; Duff et al., 1994; Tran et al., 2010a). Previous studies (e.g., Teixeira et al., 2021) have shown that soil organic matter, total N, and total $P$ have significant effects on the activity of acid phosphatase. Significant differences were observed in all experimental treatments in this study. This may stem from the fact that the growth of plant roots varies under different soil $\mathrm{N}$ supply capacities. Large roots have a higher demand for $\mathrm{P}$, which promotes the secretion of acid phosphatase by plant roots.

\section{Effects of the rate and timing of $N$ application on Yield, WUE, and NUE}

Fertilizer plays an important role in crop growth and development. Tomato absorbs moisture and nutrients from the soil through its roots, carries out photosynthesis, and synthesizes carbohydrates. $\mathrm{N}$ can regulate crop physiological processes and support crop growth (Bartkowiak et al., 2015) and is one of the most important nutrient elements for crop growth. In this study, the tomato $Y$ under irrigation was significantly higher under S2 and S3 than under S1. This mainly stems from the fact that under S1, urea is more prone to leaching downward, which concentrates the $\mathrm{NO}_{3}{ }^{-}-\mathrm{N}$ in the soil layer below $40 \mathrm{~cm}$. Under $\mathrm{S} 2$ and $\mathrm{S} 3, \mathrm{NO}_{3}{ }^{-}-\mathrm{N}$ was mostly concentrated in the $20 \sim 30 \mathrm{~cm}$ soil layer, and the taproot zone during tomato growth mainly occurs in the $20 \sim 30 \mathrm{~cm}$ soil layer, which facilitates the absorption and utilization of $\mathrm{N}$. As the $\mathrm{N}$ application rate increased, the tomato $Y$ gradually increased. There was no significant difference in tomato $Y$ between $\mathrm{N} 3$ and $\mathrm{N} 2$. As the $\mathrm{N}$ application rate increased, the effect of $\mathrm{N}$ on tomato $Y$ gradually decreased. Du et al. (2017) found that the $Y$ and $W U E$ of greenhouse tomatoes were at their highest when the $\mathrm{N}$ application rate was $250 \mathrm{~kg} \cdot \mathrm{ha}^{-1}$ in northwestern China; this is consistent with our results. 
In this study, the WUE of greenhouse tomatoes gradually increased as the $\mathrm{N}$ application rate increased, but there was no significant difference between N2 and N3. In other words, further increases in the $\mathrm{N}$ application rate slow the increasing trend in $W U E$. The NUE first increased and then decreased as the $\mathrm{N}$ application rate increased. The reason is that increases in the $\mathrm{N}$ application rate can promote the growth of crop roots (Wang et al., 2011), keep the stomata open (Bucci et al., 2006), and enhance photosynthesis (Ruiz et al., 2008), thus improving the WUE and $N U E$ of crops.

However, as the $\mathrm{N}$ application rate increases, the main factors limiting crop growth change, and the dry matter formation efficiency of crops reduces, which slows the increase in $W U E$ and decreases $N U E$ (Wang et al., 2018; Huang et al., 2003). Compared to $\mathrm{S} 1$, the distribution of $\mathrm{N}$ under $\mathrm{S} 2$ and $\mathrm{S} 3$ could improve $W U E$ and $N U E$. The reason is that $\mathrm{N}$ under $\mathrm{S} 2$ and $\mathrm{S} 3$ was concentrated in the 20 30 cm layer, which is the layer in which $\mathrm{N}$ is most accessible to crops. In the W2 stage, maintaining the $\mathrm{NO}_{3}{ }^{-}-\mathrm{N}$ content between 70 and $80 \mathrm{mg} \cdot \mathrm{kg}^{-1}$ in the $20 \sim 30 \mathrm{~cm}$ soil layer helped maintain higher WUE and $N U E$ and achieve higher tomato $Y$.

\section{Conclusions}

There are three main conclusions of this study. First, the effects of $\mathrm{N}$ application strategies on photosynthesis vary among tomato growth stages. Excessive $\mathrm{N}$ application may decrease the $P_{n}$ and $W U E_{L}$ of tomato at later growth stages. In the W2 and W3 stages, the $P_{n}$ and $W U E_{L}$ of tomato were higher under S2 and S3 than under S1. Second, soil urease activity increased non-linearly as the $\mathrm{N}$ application rate increased; the soil sucrase activity first increased and then decreased as the $\mathrm{N}$ application rate increased; soil phosphatase activity increased significantly as the $\mathrm{N}$ application rate increased. The soil enzyme activities were significantly higher under S2 and S3 than under S1. Third, the $Y$ and $W U E$ of greenhouse tomatoes increased non-linearly as the $\mathrm{N}$ application rate increased, and there were no significant differences between N3 and N2. Compared to $\mathrm{S} 1, \mathrm{~S} 2$ and $\mathrm{S} 3$ improved the $Y$ and $W U E$ of greenhouse tomato. Considering our results comprehensively, the combination of $\mathrm{N}$ injection timing of $\mathrm{S} 2$ or $\mathrm{S} 3$ (middle or last $1 / 3$ of irrigation) under $\mathrm{N}$ application rate of $\mathrm{N} 2\left(200 \mathrm{~kg} \cdot \mathrm{ha}^{-1}\right)$ is recommended as technical parameters for greenhouse tomato cultivation in arid and semi-arid sandy loam soils. However, the nitrogen application strategies need to be further studied in different regions, tomato genotypes, and soil textures.

Acknowledgments. This work is supported jointly by Natural Science Foundation of China (No. 41807041), Science and Technology Program of Xi'an (20193052YF040NS040). We are grateful for the helpful comments of the anonymous reviewers.

\section{REFERENCES}

[1] Acosta Martinez, V., Reicher, Z., Bischoff, M., Turco, R. F. (1999): The role of tree leaf mulch and nitrogen fertilizer on turfgrass soil quality. - Biology and Fertility of Soils 29: 55-61.

[2] Agbna Gamareldawla, H. D., She, D. L., Liu, Z. P., Elshaikh, N. A., Guangcheng, S., Timm, L. C. (2017): Effects of deficit irrigation and biochar addition on the growth, yield, and quality of tomato. - Scientia Horticulturae 222: 90-101. 
[3] Allen, R. G., Pereira, L. S., Howell, T. A., Jensen, M. E. (2011): Evapotranspiration information reporting: I. Factors governing measurement accuracy. - Agricultural Water Management 98: 899-920.

[4] Barth, G., von Tucher, S., Schmidhalter, U., Rafael, O., Peter, M., Risely, F. A., Thales, M. S. S., Heitor, C., Godofredo, C. V. (2019): Performance of nitrification inhibitors with different nitrogen fertilizers and soil textures. - Journal of Plant Nutrition and Soil Science 182: 694-700.

[5] Bartkowiak, S. M., Samuelson, L. J., Mcguire, M. A., Teskey, R. O. (2015): Fertilization increases sensitivity of canopy stomatal conductance and transpiration to throughfall reduction in an 8-year-old loblolly pine plantation. - Forest Ecology and Management 354: 87-96.

[6] Bucci, S. J., Scholz, F. G., Goldstein, G., Meinzer, F. C., Faranco, A. C., Campanello, P. I., Villalobos-Vrga, R., Bustamante, M., Miralles-Wilhelm, F. (2006): Nutrient availability constrains the hydraulic architecture and water relations of savannah trees. Plant Cell and Environment 29: 2153-2167.

[7] Centritto, M., Loreto, F., Massacci, A., Pietrini, F., Villani, M. C., Zacchini, M. (2000): Improved growth and water use efficiency of cherry saplings under reduced light intensity. - Ecological Research 15: 385-392.

[8] Dalal, R. C. (1975): Urease activity in some Trinidad soils. - Soil Biology and Biochemistry 7: 5-8.

[9] Du, Y. D., Cao, H. X., Liu, S. Q., Du, Y., Cao, H., Liu, S., Gu, X., Cao, Y. (2017): Response of yield, quality, water and nitrogen use efficiency of tomato to different levels of water and nitrogen under drip irrigation in Northwestern China. - Journal of Integrative Agriculture 16: 1153-1161.

[10] Duff, S. M., Sarath, G., Plaxton, W. C. (1994): The role of acid phosphatases in plant phosphorus metabolism. - Physiologia Plantarum 90: 791-800.

[11] FAO (2019): Database on Food and Agriculture Organization of the United Nations. Available at: http://www.fao.org/faostat/zh/\#data/QC.

[12] Gärdenäs, A. I., Hopmans, J. W., Hanson, B. R., Šimůnek, J. (2005): Two-dimensional modeling of nitrate leaching for various fertigation scenarios under micro-irrigation. Agricultural Water Management 74: 219-242.

[13] Hanson, B. R., Šimůnek, J., Hopmans, J. W. (2006): Evaluation of urea-ammoniumnitrate fertigation with drip irrigation using numerical modeling. - Agricultural Water Management 86: 102-113.

[14] Havlin, J. L., Beaton, J. D., Tisdale, S. L., Nelson, W. L. (2006): Soil Fertility and Fertilizers. 7th Ed. - Prentice Hall of India, New Delhi.

[15] Huang, M., Dang, T., Gallichand, J., Goulet, M. (2003): Effect of increased fertilizer applications to wheat crop on soil-water depletion in the Loess Plateau, China. Agricultural Water Management 58: 267-278.

[16] Huang, G. B., Huang, C., Feng, F. X., Yu, A. Z. (2012): Effects of different tillage systems on soil properties, root growth, grain yield, and water use efficiency of winter wheat (Triticum aestivum L.) in arid Northwest China. - Journal of Integrative Agriculture 11: 1286-1296.

[17] Hussain, M., Farooq, M., Nawaz, A., Al-Sadi, A. M., Solaiman, Z. M., Alghamdi, S. S., Ammara, U., Ok, Y. S., Siddique, K. H. M. (2017): Biochar for crop production: potential benefits and risks. - Journal of Soils Sediments 17: 685-716.

[18] Ibrahim, M. M., Tong, C., Hu, K.., Zhou, B. Q., Xing, S. H., Mao, Y. L. (2020): Biocharfertilizer interaction modifies $\mathrm{N}$-sorption, enzyme activities and microbial functional abundance regulating nitrogen retention in rhizosphere soil. - Science Total Environment 739: 140065.

[19] Ju, X. T., Kou, C. L., Zhang, F. S., Christie, P. (2006): Nitrogen balance and groundwater nitrate contamination: Comparison among three intensive cropping systems on the North China Plain. - Environmental Pollution 143: 117-125. 
[20] Kaushal, T., Onda, M., Ito, S., Yamazaki, A., Fujikake, H., Ohtake, N., Sueyoshi, K., Takahashi, Y., Ohyama, T. (2005): $15 \mathrm{~N}$ analysis of the promotive effect of deep placement of slow-release $\mathrm{N}$ fertilizers on growth and seed yield of soybean. - Soil Science \& Plant Nutrition 51: 885-892.

[21] Khakural, B. R., Alva, A. K. (1995): Hydrolysis of urea in two sandy soils under citrus production as influenced by rate and depth of placement. - Communications in Soil Science and Plant Analysis 26: 2143-2456.

[22] Kim, H., Kang, H. (2011): The impacts of excessive nitrogen additions on enzyme activities and nutrient leaching in two contrasting forest soils. - Journal of Microbiology 49: 369-375.

[23] Li, J., Zhang, J., Rao, M. (2004): Wetting patterns and nitrogen distributions as affected by fertigation strategies from a surface point source. - Agricultural Water Management 67: 89-104.

[24] Li, H. H., Liu, H., Gong, X. W., Li, S., Pang, J., Chen, Z. F., Sun, J. S. (2021): Optimizing irrigation and nitrogen management strategy to trade off yield, crop water productivity, nitrogen use efficiency and fruit quality of greenhouse grown tomato. Agricultural Water Management 245: 106570.

[25] Liu, E. K., Yan, C. R., Mei, X. R., He, W. Q., Bing, S. H., Ding, L. P., Liu, Q., Liu, S., Fan, T. L. (2010): Long-term effect of chemical fertilizer, straw, and manure on soil chemical and biological properties in northwest China. - Geoderma 158: 173-180.

[26] Liu, H., Duan, A., Li, F., Sun, J. S., Wang, Y. C., Sun, C. T. (2013): Drip irrigation scheduling for tomato grown in solar greenhouse based on pan evaporation in North China Plain. - Journal of Integrative Agriculture 12: 520-531.

[27] Liu, H., Li, H., Ning, H., Zhang, X. X., Li, S., Pang, J., Wang, G. H., Sun, J. S. (2019): Optimizing irrigation frequency and amount to balance yield, fruit quality and water use efficiency of greenhouse tomato. - Agricultural Water Management 226: 105787.

[28] Luo, Z. K., Tang, Z. X., Guo, X. W., Jiang, J., Sun, O. J. X. (2020): Non-monotonic and distinct temperature responses of respiration of soil microbial functional groups. - Soil Biology and Biochemistry 148: 107902.

[29] Mahajan, G., Singh, K. G. (2006): Response of greenhouse tomato to irrigation and fertigation. - Agricultural Water Management 84: 202-206.

[30] Marcote, I., Hernández, T., García, C., Polo, A. (2001): Influence of one or two successive annual applications of organic fertilizers on the enzyme activity of a soil under barley cultivation. - Bioresource Technology 79: 147-154.

[31] Matimati, I., Verboom, G. A., Cramer, M. D. (2014): Nitrogen regulation of transpiration controls mass-flow acquisition of nutrients. - Journal of experimental botany 65: 159168.

[32] Min, J., Zhang, H., Shi, W. (2012): Optimizing nitrogen input to reduce nitrate leaching loss in greenhouse vegetable production. - Agricultural Water Management 111: 53-59.

[33] Nafi, E., Webber, H., Danso, I., Naab, J. B., Frei, M., Gaiser, T. (2019): Soil tillage, residuemanagement and site interactions affecting nitrogen use efficiency in maize and cotton in the Sudan Savanna of Africa. - Field Crops Research 244: 107629.

[34] Outoukarte, I., Belaqziz, M., Price, A., Nsarellah, N., Hadrami, I. E. (2010): Durum Wheat Root Distribution and Agronomical Performance as Influenced by Soil Properties. - Crop Science 50: 803.

[35] Qiu, R., Du, T., Kang, S. (2017): Root length density distribution and associated soil water dynamics for tomato plants under furrow irrigation in a solar greenhouse. - Journal of Arid Land 9: 637-650.

[36] Rashti, M. R., Wang, W. J., Moody, P., Chen, C. R., Hossein, G. (2015): Fertilizerinduced nitrous oxide emissions from vegetable production in the world and the regulating factors: a review. - Atmospheric Environment 112: 225-233. 
[37] Ren, C., Zhou, Z., Guo, Y., Yang, G., Zhao, F., Wei, G., Han, X., Feng, L., Feng, Y., Ren, G. (2021): Contrasting patterns of microbial community and enzyme activity between rhizosphere and bulk soil along an elevation gradient. - Catena 196: 104921.

[38] Ruiz, M., Aguiriano, E., Carrillo, J. M. (2008): Effects of N fertilization on yield forlowinput production in Spanish wheat landraces (Triticum turgidum L. and Triticum monococcum L.). - Plant Breed 127: 20-23.

[39] Shi, W., Ju, Y. Y., Bian, R. J., Li, L. Q., Joseph, S., Mitchell, D. R. G., Munroe, P., Taherymoosavi, S., Pan, G. Z. (2020): Biochar bound urea boosts plant growth and reduces nitrogen leaching. - Science of the Total Environment 701: 134424.

[40] Taylor, C. B., Bariola, P. A., delCardayre, S. B., Raines, R. T.; Green, P. J. (1993): RNS2: a senescence-associated RNase of Arabidopsis that diverged from the S-RNases before speciation. - Proceedings of the National Academy of Sciences of the United States of America 90: 5118-5122.

[41] Teixeira, A. F. D. S., Silva, S. H. G., Carvalho, T. S. D., Silva, A. O., Guimaraes, A. A., Moreira, F. M. S. (2021): Soil physicochemical properties and terrain information predict soil enzymes activity in phytophysiognomies of the Quadrilátero Ferrífero region in Brazil. - Catena 199: 105083.

[42] Toor, R. K., Savage, G. P., Heeb, A. (2006): Influence of different types of fertilisers on the major antioxidant components of tomatoes. - Journal of Food Composition and Analysis 19: 20-27.

[43] Tran, H. T., Hurley, B. A., Plaxton, W. C. (2010): Feeding hungry plants: the role of purple acid phosphatases in phosphate nutrition. - Plant Science 179: 14-27.

[44] Wang, Q. K., Wang, S. L., Liu, Y. X. (2008): Responses to N and P fertilization in a young Eucalyptus dunnii plantation: microbial properties, enzyme activities and dissolved organic matter. - Applied Soil Ecology 40: 484-490.

[45] Wang, J., Liu, W., Dang, T. (2011): Responses of soil water balance and precipitation storage efficiency to increased fertilizer application in winter wheat. - Plant Soil 347: 4151.

[46] Wang, C. H., Zhu, F., Zhao, X., Dong, K. H. (2014): The effects of N and P additions on microbial $\mathrm{N}$ transformations and biomass on saline-alkaline grassland of Loess Plateau of northern China. - Geoderma 213: 419-425.

[47] Wang, L. L., Palta, J. A., Chen, W., Chen, Y. L., Deng, X. P. (2018): Nitrogen fertilization improved water-use efficiency of winter wheat through increasing water use during vegetative rather than grain filling. - Agricultural Water Management 197: 41-53.

[48] Zhang, M. Z., Niu, W. Q., Bai, Q. J., Li, Y., Wang, J. W., Wang, Z. Q., Zhang, Z. X. (2020): Improvement of quality and yield of greenhouse tomato (Solanum lycopersicum L.) plants by micro-sprinkler irrigation under plastic film. - Applied Ecology and Environmental Research 18(5): 6905-6926.

[49] Zhao, W. X., Cai, H. J.., Shan, Z. J., Chen, X. M., Wang, J. (2009): High yield indicators of greenhouse tomato under non-pressure irrigation. - Transactions of the Chinese Society of Agricultural Engineering 25: 16-21 (in Chinese with English abstract).

[50] Zhou, H. P., Kang, S. Z., Li, F. S., Du, T. S., Shukla, M. K., Li, X. J. (2020): Nitrogen application modified the effect of deficit irrigation on tomato transpiration, and water use efficiency in different growth stages. - Scientia Horticulturae 263: 102-113.

[51] Zhu, Z., Chen, D. (2002): Nitrogen fertilizer use in China-Contributions to food production, impacts on the environment and best management strategies. - Nutrient Cycling in Agroecosystems 63: 117-127. 